\title{
Capital Inflows and Industrial Performance in Nigeria: Including the Excluded
}

\author{
Ibrahim Ayoade Adekunle*1, Ayomide Olayinka Ogunade ${ }^{1}$, Toluwani \\ Grace Kalejaiye $^{2}$, and Adewale Musliudeen Balogun ${ }^{1}$
}

\section{OPEN}

\section{AFFILIATION:}

${ }^{1}$ Olabisi Onabanjo University. Ago Iwoye, Ogun State, Nigeria.

${ }^{2}$ Tai Solarin University of Education. Ijebu-Ode, Ogun State, Nigeria.

\section{*CORRESPONDENCE:}

adekunle_ia@yahoo.com

\section{THIS ARTICLE IS AVALILABLE IN:}

http://journal.umy.ac.id/index.php/esp

DOI: 10.18196/jesp.21.1.5030

\section{CITATION:}

Adekunle, I. A., Ogunade, A. O., Kalejaiye, T. G., \& Balogun, A. M. (2020). Capital Inflows and Industrial Performance in Nigeria: Including the Excluded. Jurnal Ekonomi \& Studi Pembangunan, 21(1), 37-52.

\section{ARTICLE HISTORY}

\section{Received:}

12 December 2019

Reviewed:

31 December 2019

19 April 2020

Revised:

6 February 2020

22 April 2020

Accepted:

22 April 2020

\begin{abstract}
Africa's most populous black nations remain underdeveloped, mainly due to shambolic industrial sector performance. The rising problems of insecurity, corrupt practices, and consumerism structure have made gains from capital inflows minimal. Little empirical credence has been leaned to the capital inflowindustrial output growth relationship in Nigeria. This anomaly has resulted in short-sighted policy formulation and attendant consequences. This paper examined international capital flows and industrial performance in Nigeria. The paper employed the two-step Engle and Granger estimation procedure and the Granger Causality to estimates parameters of the indices of industrial output growth and capital inflows to Nigeria. Findings revealed that labour participation, gross fixed capital formation, foreign direct investment (FDI), and portfolio investment had a significant positive relationship with industrial performance in Nigeria. Findings also revealed unidirectional causality from labour participation, gross fixed capital formation, foreign direct investment (FDI) and portfolio investment to industrial performance in Nigeria. Based on the findings, the Nigerian government should create an enabling environment to attract more capital inflow that could augment domestic resources with the sole aim of growing the industrial sector.

Keywords: Capital inflow; Industrial performance; Error Correction Model (ECM); Granger causality.

JEL Classification: C22, F21, P47.
\end{abstract}

\section{Introduction}

African leaders and their development partners around the world are continuously engaged in ensuring poverty is sabotaged in and around the continent. Several measures of poverty eradication have been adopted with minimal impact (Carter \& May 1999). With the Africa 2063 Agenda in focus, industrial growth and development remain the most pervasive option for Africa to gain momentum for structural transformation. Theoretical and empirical findings (see Aryeetey \& Moyo, 2012; Bräutigam \& Xiaoyang, 2011; Morris \& Fessehaie, 2014; Okereke Coke, Geebreyesus, Ginbo, Wakeford, \& Mulugetta, 2019; Taylor, 2016 for some examples) leaned credence to the revolutionary industrial growth in African economies and confirm that more strategic industries will not only help African countries to amass affluence but also help solve the age-old problems of redundancy that have redefined their teeming populations. Industrial growth offers viable paths for skill and technology advancement 


\author{
Adekunle, Ogunade, Kalejaiye, \& Balogun \\ Capital Inflows and Industrial Performance in Nigeria: Including the Excluded
}

(Aryeetey \& Moyo, 2012), wealth creation (Morris \& Fessehaie, 2014), youth engagement (Okereke et al., 2019), economic divergence (Oyelaran-Oyeyinka, 2014) and many more. Thus, it is adjudged to be the most relevant for many African countries, particularly Nigeria (World Bank, 2014). The ability of a well-equipped industrial sector to absorb unskilled and semi-skilled workforce is second to no other sector in an economy (Daveri \& Tabellini, 2000). Industrialised Africa will be famous not for the commodities-based economic approach but rather because of its potentials for higher value-addition and its ability to protects the economy from the shocks in global commodity markets (Morris \& Fessehaie, 2014). African countries, such as Ethiopia, Kenya, Nigeria, and South Africa, have begun to intensify efforts to leverage their comparative advantages through specific industrial development programmes to break the established global manufacturing value chains in many commodities, such as textiles, metal processing, leather, agro-processing primary (World Bank, 2013). Even the industrialised nations (the G7-Canada, Germany, France, Italy, Japan, UK, and the US) operating service-based economies are recently looking for an inventive approach to re-shore their manufacturing (a core of industrialisation) to seizure deteriorating growth and employment prospects that are in the time past absent (Mahipal \& Prasad, 2004). In clear terms, the importance of industrial output growth can never be overstated, not least when it comes to the context of development in Nigeria.

With so much attention going into industrial output growth these days, the questions are many and unanswered. How relevant is capital inflows to Nigeria as a determinant of industrial output growth objectives? What is the nature and volume of capital inflow? How much of it goes to the industrial sector? Moreover, how well do they predict variations in industrial output growth in Nigeria? These are quite essential questions seeing how the industrial sector has always been a significant contributor to growth outcomes. With increasingly more countries allowing for cross-border capital mobility, the impact of capital inflows on industrial output has become a matter of considerable policy relevance. Theoretically, capital inflows can increase access to finance of industries and, thereby, promote industrial investment growth, expenditure smoothing, and international risk sharing that boost investors' confidence. Knowing how capital flows induce changes in industrial output growth in Nigeria to remain grossly understudied in the extant literature of public finance. Apparently, no country-specific study has examined capital flows for industrial output growth in Nigeria. Given the growing sophistication of capital flow to Nigeria because of rising problems of insecurity and terrorism, weak institutional frameworks, arbitrage motives of hedging, exchange rate fluctuations, more recent research has focused on identifying types of capital flow that enhance economic growth. Little attention has been paid to the role of capital flow-industrial output growth relationship in Nigeria.

Another essential issue that has generated debate is the role of capital inflow to jumpstart the growth of the industrial sector. A growing list of studies found a positive relationship between financial openness, capital mobility, and economic growth (see De Gregorio \& Guidotti, 1995; Levine, 1997; Rajan \& Zingales, 1998, for example). However, Gourinchas and Jeanne (2006) found that welfare gains accruing to the industrial sector when finances are sourced across borders to augment domestic savings are negligible relative to the welfare gain of take-off when industrial growth in domestic sponsored. The 


\section{Adekunle, Ogunade, Kalejaiye, \& Balogun \\ Capital Inflows and Industrial Performance in Nigeria: Including the Excluded}

arguments are hinged on the fact that capital inflow to African countries are motivated by the act of capitalism from the sending countries (arguments are advanced for inflows from Europe and North America). A capitalist-motivated capital flow leaves damaging effects on recipient countries in the event of withdrawal of capital, leading to capital flight (Efobi \& Asongu, 2016). Thus, it leaves an enormous investment gap that creates further economic problems. However, non-capitalist motivated capital flows are growth and development inclined and thus sustainable (arguments are advanced for inflows from China and other Asian countries). Since the onset of the evaluation of gains from capital flows, the structural relationship with industrial development remains dimly discerned in Nigeria, mainly as it concerns the primary effect of these capital flows for structural transformation, which largely hinge on the shift from agrarian to an industrialised economy. It is not even entirely clear how capital flow predicts variations in the industrial sector of Nigeria. A growing list of studies (see Akinlo, 2004; Buera \& Shin, 2017; Osinubi \& Amaghionyeodiwe, 2010) has focused on the capital flow-economic growth nexus neglecting the underlying structural dynamics of capital flow as a predictor of industrial output growth in Nigeria.

The industrial development pattern of developing countries has remained sticky even when additional foreign investment from abroad is injected (Markusen, 1996). Despite the conventional relationship between foreign direct investment flows and growth outcomes moving symmetrically, no evidence providing additional financing over domestic savings ultimately leads to industrialisation (Brandl \& Traxler, 2010). It is clear that the inflow of funds spur industrial growth but remains unclear is the magnitude of change in industrial output as a result of the rate of change in capital inflow. Prasad, Rajan, and Subramanian (2007), in contrast to standard theoretical economic growth models, argued that developing countries with low-level industrialisation that have relied more on foreign finance had not grown faster in the long run. Similarly, Aizenman, Pinto, and Radziwill (2007) argued that the economic growth of developing and emerging markets was relatively self-financed when comparing the value of domestic capital against the foreign inflow of funds.

This study attempts to lean empirical credence to the capital inflow-industrial output growth relationship in Nigeria to inform policy direction and research. We adopt a country-specific analytical approach to examine the predictive capacity of capital inflow for industrial output growth in Nigeria. We quantify the relationship in their evolution over time by rolling the regressions forward over 31 years. Finally, we evaluate the impact of critical variables focusing on Nigeria, which is an economy representative of the African periphery. We conducted the Granger Causality test to evaluate the direction of causality between the variables of interest. We justified that our model does not violate any of the assumptions of the classical linear regression model by conducting the various post estimation procedure that confirms the reliability of estimates emanating from this study. The novelty of the research is in two folds: this study leads the debate on the capital inflows-industrial output growth in Nigeria with the aim of coming up with findings that can redefine policy and research on the subject matter. This study analyses a new perspective by disaggregating capital inflows to study which of the capital inflows channels has the most domineering influence on industrial sector performance in Nigeria. 


\section{Adekunle, Ogunade, Kalejaiye, \& Balogun \\ Capital Inflows and Industrial Performance in Nigeria: Including the Excluded}

By intuition, policy formulation can be tailored towards encouraging such channel of capital inflow well above other channels for industrial sector growth and subsequently development. The subsequent sections are the literature review, the methodology used, then the empirical results and their corresponding interpretations and discussion while the last part gives the conclusion and policy recommendations.

Capital inflow and industrial output growth have been discussed along various dimensions and geographical landscapes. Oseni, Adekunle, and Alabi (2019) found volatility in the exchange rate to predict significant variations in industrial output growth in Nigeria. In related findings, Jongbo (2014) advanced arguments for the fluctuating exchange rate as a predictor of industrial sector performance. The author relied on the ordinary least square and found that the real exchange rate significantly induced variations in industrial sector performance in Nigeria. With the attendant heterogeneous influence of exchange rate fluctuations, which could appreciate or depreciate, industrial sector performance bows to pressures of exchange rate fluctuations. Furthermore, Adeniyi, Oyinlola, and Omisakin (2011) established a linear and positive influence of the exchange rate on the industrial sector in Nigeria. In other findings, Okafor, Adegbite, and Abiola (2018) found the exchange rate and inflation shock to hurt the growth of the industrial sector in Nigeria. It was evident from the review of literature that the contemporaneous influence that capital inflows play in the industrial sector development of Nigeria remains grossly understudied.

In other country studies that are not entirely on the exact structural relationship between capital inflow and industrial performance in Nigeria, Ojedide (2005) studied capital flows volatility and macroeconomic performance in Nigeria and found that capital flows are a function of the initial stage of the developing country. Consequent to the above, we tested the hypothesis that capital inflows would propel the growth in the industrial sector of Nigeria, assuming initial conditions were met. In a trivariate country analysis, Herzer (2006) relied on the bivariate Vector Autoregressive (VAR) estimation procedure to study the FDI-growth causal relationship in Nigeria, Srilanka, Tunisia, and Egypt. Findings revealed that FDI catalysed the productivity of the manufacturing sector, which in turn speeded up the growth rate of the Gross Domestic Product of the countries. Using the two-step Engle and Granger estimation procedure, Steve, Samuel, and Bodiseowei (2013) found domestic debt to influence foreign aid positively while debt inversely predicted economic growth. In their analysis of capital outsourcing and growth of the manufacturing sector, Ugwu, Asogwa, and Ugwuanyi (2017) found FDI to predict variations in economic growth significantly.

In other climes and across borders, Mensah, Awunyo-Vitor, and Asare-Menako (2013) argued that volatility in exchange rate determined Ghana's manufacturing sector employment growth. Based on the empirical credence, we opine that the devaluation of the Ghanian Cedis relative to the U.S. Dollars could be responsible for the inefficient industrial sector in Ghana. Nonetheless, UNECA (2009) found that religious tension, productive and non-productive risks, percentage of oil in total exports, current market size, the volume of FDI inflow, pervasive corruption, saving ration, nominal credit to the private sector were critical determinants of FDI inflows in Africa. Ojo and Alege (2010) 
corroborated the findings of UNECA in their empirical analysis of the impact of global financial crisis and policy implications on the sudden rise in FDI inflows in twenty-seven (27) economies in Sub Saharan Africa. The authors found that output growth co-moved with the inflows of FDI in Africa. In other related studies, Chakarabarti (2001) found that market factors were the principal determinant of FDI inflows to Africa. Besides, FDI inflows were sensitive to real exchange rate movements in Sub-Saharan Africa (Ogun, Egwaikkhide \& Ogunleye, 2012).

We conclude that little has been done on the empirical validation of capital inflowindustrial output growth relationship in Nigeria. Evidence on the industrial sector performance in Nigeria has been studied against the volatility or fluctuations in the exchange rate. How remittances inflows, foreign direct investment, portfolio investment, and official development assistance in the form of aid predicts variation in Nigeria industrial development remains dimly discerned. The intricacies of such omission in the literature of industrial sector development in Nigeria underpin this study. Consequent on the above, we tested the hypothesis that:

$H_{0}$ : Capital Inflow has no significant relationship with industrial output growth in Nigeria

$\mathrm{H}_{1}$ : $\quad$ Capital Inflow has a significant relationship with industrial output growth in Nigeria

\section{Research Method}

In accounting for industrial performance as induced by capital inflow in Nigeria, the study followed the dual gap theory. Developing countries like Nigeria rely on the inflow of funds to augments the savings-investment gap. The equilibrating condition of the dual-gap model occurs at:

$$
S_{t}=I_{t}
$$

With $S_{t}$ representing the national savings level and $I_{t}$ is the predominant investment level. Nigeria has been predominantly characterized by the low level of domestic savings amidst lofty investment objectives so that we obtained the savings investment-gap, which created a vacuum for external capital inflow to augment domestic savings to meet the lofty investment objectives. The functional relationship of such relationship is expressed as:

$$
S_{t}+\text { CAP }_{\text {FLOW }}=I_{t}
$$

Unvaryingly, we re-evaluated our capital stock function to include all forms of capital inflows:

$$
K_{t}=S_{t}+\text { CAP }_{\text {FLOW }}+(1-\delta) K_{t-1}=I_{t}
$$


where $\mathrm{K}_{\mathrm{t}}$ defines the capital stock parameter, $\mathrm{S}_{\mathrm{t}}$ is the national savings level, $C A P_{F L O W_{t}}$ is the capital inflow options to the country, $\delta$ measures depreciation of capital, and $I_{t}$ is the predominant investment level.

We proceed to estimate the industrial performance model in a Cobb-Douglas production function.

$$
Y_{t}=A L_{t}^{1-\propto} K_{t}^{\propto}
$$

$Y_{t}$ represents the output growth of the industry; $L_{t}$ measures output per unit of effective labour; $\mathrm{K}_{\mathrm{t}}$ represents output per unit of effective capital, and $C A P_{F L O W_{t}}$ is the capital inflows to the country. The capital inflow-industrial output growth induced model is expressed as:

$$
I N D_{\text {OUT }_{t}}=A+\sum_{i}^{n=1} \gamma_{n} A L_{t}+\sum_{i}^{n=1} \pi_{n} K_{t}+\sum_{i}^{n=1} \omega_{n} \text { CAP }_{\text {FLOW }_{t}}+\mu_{t}
$$

where $\gamma, \pi$, and $\omega$, are the elasticities of human capital (L), physical capital (K), and capital flows, respectively. IN $D_{O U T_{t}}$ is industrial output growth in Nigeria, $A$ is the efficiency of the productive economy, $A L$ is labour force or the working population, $k_{t}$ is domestic capital stock, $C A P_{F L O W_{t}}$ is a capital inflow to Nigeria, and $t$ is the time series characteristics of the data set (1987-2017). Given the purpose of this study which is to examine the effect of capital flow on industrial output growth, we took the semi-logarithms and time derivatives of equation (5) to generate the following dynamic function:

$$
\operatorname{lnIND_{OUT_{t}}}=A+\sum_{i}^{n=1} \gamma_{n} A L_{t}+\sum_{i}^{n=1} \pi_{n} \ln K_{t}+\sum_{i}^{n=1} \omega_{n} \operatorname{lnCAP}_{\text {FLOW }_{t}}+\mu_{t}
$$

Explicitly, the explanatory model intended to capture the dynamics of industrial output growth was expressed in equation (7)

$$
\begin{aligned}
& \operatorname{lnIND_{\text {OUT}_{t}}}=A+\sum_{i}^{n=1} \gamma_{n} A L_{t}+\sum_{i}^{n=1} \pi_{n} \ln K_{t}+\sum_{i}^{n=1} \omega_{n} \operatorname{lnFDI_{t}}+\sum_{i}^{n=1} \emptyset_{n} \operatorname{lnREM_{t}+} \\
& \sum_{i}^{n=1} \infty_{n} \ln O D A_{t}+\sum_{i}^{n=1} \partial_{n} \operatorname{lnPORT}_{I N V_{t}}+\mu_{t}
\end{aligned}
$$

where $\gamma, \pi, \omega, \emptyset, \infty$, and $\partial$, are the elasticities of human capital (L), physical capital (K), FDI, remittances, official development assistance, portfolio investment, respectively. $I N D_{O U T_{t}}$ is industrial output growth in Nigeria, $A$ is the efficiency of the productive economy, $A L$ is labour force or the working population, $k_{t}$ is domestic capital stock, $F D I$ is the foreign direct investment to Nigeria, $R E M$ is remittances inflow to Nigeria, $O D A$ is official development assistance to Nigeria, $P O R T_{I N V}$ is portfolio investment to Nigeria, $t$ defines the time parameter of the model.

Our study used annual time series data for indices of capital flows and industrial output growth from 1987 through 2017. The choice of Nigeria was guided by the desire to explain the structural transformation of the Nigerian industrial sector with the attendant consequences of capital inflows. This study was also guided by the availability of reliable data on aggregates of capital inflows and associative consequences. Capital inflows were measured employing foreign direct investment, official development assistance, portfolio investment, and remittances as used in the work of Edwards (1990); Calvo (1998); Reisen 
Table 1 Variable Description

\begin{tabular}{|c|c|c|c|}
\hline Abbreviation & Variable & Measured As & Source \\
\hline$I N D_{\text {out }_{t}}$ & $\begin{array}{l}\text { Industrial Output } \\
\text { Growth in Nigeria }\end{array}$ & Industry Value Added & $\begin{array}{l}\text { World Development Indicator } \\
\text { (WDI), } 2017\end{array}$ \\
\hline$A L_{i t}$ & Labour & Labour Participation Rate & $\begin{array}{l}\text { World Development Indicator } \\
\text { (WDI), } 2017\end{array}$ \\
\hline$K_{i t}$ & Capital Stock & Gross Fixed Capital Formation & $\begin{array}{l}\text { World Development Indicator } \\
\text { (WDI), } 2017\end{array}$ \\
\hline FDI & $\begin{array}{l}\text { Foreign Direct } \\
\text { Investment }\end{array}$ & $\begin{array}{l}\text { Net Foreign Direct Investment } \\
\text { Inflows }\end{array}$ & $\begin{array}{l}\text { World Development Indicator } \\
\text { (WDI), } 2017\end{array}$ \\
\hline REM & Remittance & Remittances Inflows & $\begin{array}{l}\text { World Development Indicator } \\
\text { (WDI), } 2017\end{array}$ \\
\hline$O D A$ & $\begin{array}{l}\text { Official } \\
\text { Development } \\
\text { Assistance }\end{array}$ & $\begin{array}{l}\text { Official Development } \\
\text { Assistance to developing } \\
\text { nations }\end{array}$ & $\begin{array}{l}\text { World Development Indicator } \\
\text { (WDI), } 2017\end{array}$ \\
\hline PORT $_{I N V}$ & $\begin{array}{l}\text { Portfolio } \\
\text { Investment }\end{array}$ & Portfolio Investment & $\begin{array}{l}\text { World Development Indicator } \\
\text { (WDI), } 2017\end{array}$ \\
\hline
\end{tabular}

Source: Authors, 2020

and Soto (2001); Schneider (2003); De Vita and Kyaw (2008); Opperman and Adjasi (2017). However, industrial output growth was measured utilizing industry value added as in Bandyopadhyay, Sandler, and Younas (2014); Bezić, Galović, and Mišević (2016); Filer and Stanišić (2016); Galović, Bezić, and Mišević (2018). We relied on data from the World Bank Database (World Bank, 2017). The variables used in this study are described in Table 1.

We presented the pre-estimation analysis from the descriptive statistics and the unit root test. The descriptive analysis confirmed the normality condition of the data sets. The unit root establishes the order of integration of the variables and subsequently informs the estimation strategy to be adopted. We proceed to estimate the cointegration test to confirm the existence of long-run covariance among the variables (Johansen \& Juselius, 1990; Pesaran \& Shin, 2012; Wang \& Wu, 2012). The Trace Statistics and Maximum Eigenvalue can be estimated from the Eigenvalues of the coefficient matrix. We proceed to estimate the two-step Engle and Granger estimation procedure to adjust long runconvergence behaviour to suit gradual short-run equilibrium (Engle \& Granger, 2015). Also, we estimated the Granger causality test to determine the lag-order in the causation model (Eichler, 2007).

\section{Result and Discussion}

The descriptive statistics of the data provided vital information about the sample series, such as the mean, median, minimum and maximum values, and the distribution of the sample measured by the skewness, kurtosis, and Jaque-Bera statistics.

The summary statistics result in Table 2 reveals a high tendency for normal distribution (mean and median values lie within the maximum and minimum values). We found positively skewed series and platykurtic distributions with flat tail relative to the normal distribution (values less than three (3)). We discovered the series to be normally 
Adekunle, Ogunade, Kalejaiye, \& Balogun

Capital Inflows and Industrial Performance in Nigeria: Including the Excluded

Table 2 Descriptive Statistics

\begin{tabular}{|c|c|c|c|c|c|c|c|}
\hline $\begin{array}{l}\text { Descriptive } \\
\text { Statistics }\end{array}$ & $I N D_{\text {OUT }_{t}}$ & $L_{t}$ & $K_{t}$ & $F D I_{t}$ & $R E M_{t}$ & $O D A_{t}$ & $\mathrm{PORT}_{I N V_{t}}$ \\
\hline Mean & 7.5001 & 3.3613 & 2.6501 & 4.7086 & 3.3613 & 2.6502 & 4.7086 \\
\hline Median & 7.4401 & 3.0121 & 2.9101 & 3.9492 & 3.0121 & 2.9101 & 3.9492 \\
\hline Maximum & 9.1101 & 8.8325 & 3.9901 & 5.4258 & 4.8326 & 3.5421 & 5.4258 \\
\hline Minimum & 5.2301 & 0.6426 & 1.6209 & 2.2513 & 1.6426 & 1.6439 & 2.2232 \\
\hline Std. Dev. & 2.0001 & 2.2081 & 8.3209 & 3.5653 & 2.2081 & 2.4303 & 1.3368 \\
\hline Skewness & 1.3093 & 1.8801 & 1.5863 & 1.9769 & 1.8801 & 2.5863 & 2.9769 \\
\hline Kurtosis & 1.6697 & 2.9775 & 2.1772 & 1.0603 & 2.9772 & 2.1707 & 2.2357 \\
\hline Jargue-Bera & 2.3312 & 2.4533 & 2.2349 & 4.1402 & 3.4221 & 2.2342 & 1.1046 \\
\hline Probability & 0.3016 & 0.5562 & 0.2305 & 0.1183 & 0.4302 & 0.3271 & 0.5126 \\
\hline Observation & 31 & 31 & 31 & 31 & 31 & 31 & 31 \\
\hline
\end{tabular}

Source: Authors, 2020

distributed consequent upon probability values that were non-significant at a $5 \%$ level of significance.

Unit Root Test

Table 3 Unit Root Test: Augmented Dickey-Fuller Test (ADF)

\begin{tabular}{|c|c|c|c|c|c|}
\hline Variables & Level T-Stat & $\begin{array}{c}\text { Critical Value } \\
@ 5 \%\end{array}$ & $\begin{array}{c}\text { First } \\
\text { Difference } \\
\text { T-Stat }\end{array}$ & $\begin{array}{c}\text { Critical Value } \\
@ 5 \%\end{array}$ & $\begin{array}{c}\text { Order of } \\
\text { Integration }\end{array}$ \\
\hline$I N D_{o U T_{t}}$ & -0.5773 & -3.3737 & -4.3332 & -1.4334 & I (1) \\
\hline$A L_{i t}$ & -1.3323 & -2.4333 & -3.4331 & -2.5888 & I (1) \\
\hline$K_{i t}$ & 0.7447 & -1.5531 & -3.2332 & -1.6632 & I (1) \\
\hline$F D I$ & 3.5523 & -1.8203 & -4.6682 & -3.5626 & I (1) \\
\hline REM & -2.3682 & -5.5236 & -3.6362 & -1.3322 & I (1) \\
\hline$O D A$ & 1.1221 & 1.0032 & -2.3222 & -1.3222 & I (1) \\
\hline$P O R T_{I N V}$ & -1.3772 & -2.9511 & -2.6631 & -1.57231 & $I(1)$ \\
\hline
\end{tabular}

Source: Authors, 2020

Note: The summary statistics were computed before taking the natural logs

We found the first differenced stationarity order across all series in the data set. We proceed to estimate the two-step Engle and Granger error correction estimation procedure to gradually adjust from the long run converging characteristics of the variables to the short-run equilibrating position. The error correction model thwarts long-run convergence in the parameterisation of the variables for short-run gradual equilibrium (Engle \& Granger, 2015). The error correction model to be estimated is specified as:

$$
\begin{aligned}
& \operatorname{lnIND_{OUT_{t}}}=A+\sum_{i}^{n=1} \gamma_{n} A L_{t}+\sum_{i}^{n=1} \pi_{n} \ln K_{t}+\sum_{i}^{n=1} \omega_{n} \operatorname{lnFDI_{t}}+\sum_{i}^{n=1} \emptyset_{n} \operatorname{lnREM}_{t}+
\end{aligned}
$$

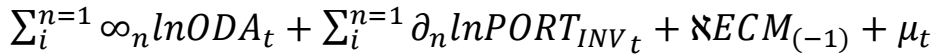

All other variables remained as earlier defined except $E C M_{(-1)}$ which is the error correction component of the model that gradually adjust frontal long-run convergence to short-run equilibrating conditions, and $\mathrm{N}$ is the coefficient of the error correction component that gives the speed of adjustment back to short term equilibrium. 


\section{Optimal Lag Length Selection}

Table 4 Optimal Lag Length Selection

\begin{tabular}{cc}
\hline Lag length & AIC \\
\hline 0 & 4.7838 \\
1 & $2.5622^{*}$ \\
\hline
\end{tabular}

Source: Authors, 2020

Notes * indicates lag order selected by the criterion

Error correction modelling procedure is sensitive to lag length because of the time-varying parameters of the model adjustment. We relied on the Akaike Information Criteria to choose the optimal lag length for our industrial performance model. The information criteria with the lowest statistics in the corresponding lag-order selection give the optimal.

Lag length one (1) is optimal based on the result presented in Table 4. We proceed to established cointegrating level and short-run elasticities.

\section{Cointegration Test}

We drew inferences at 5\% in the Tace and Maximum Eigen Values Statistics.

Table 5 Result of Johansen Co-integration test based on Trace Statistic and Max Eigenvalue

\begin{tabular}{|c|c|c|c|c|c|c|c|}
\hline \multirow[b]{2}{*}{ No. of CE(s) } & \multicolumn{3}{|c|}{ Trace Statistic } & \multicolumn{4}{|c|}{ Max. Eigen Value } \\
\hline & Eigenvalue & $\begin{array}{c}\text { Trace } \\
\text { Statistic }\end{array}$ & $\begin{array}{c}0,05 \\
\text { Critical } \\
\text { Value }\end{array}$ & Prob. & $\begin{array}{l}\text { Max- } \\
\text { Eigen } \\
\text { Value }\end{array}$ & $\begin{array}{l}\text { Critical } \\
\text { Value }\end{array}$ & Prob. \\
\hline None * & 0.74 & 138.42 & 95.75 & $0.00 *$ & 44.52 & 40.10 & $0.01^{*}$ \\
\hline At most $1 *$ & 0.69 & 93.91 & 69.82 & $0.00^{*}$ & 38.61 & 33.88 & $0.01^{*}$ \\
\hline At most $2^{*}$ & 0.53 & 55.29 & 47.86 & $0.01 *$ & 25.50 & 27.58 & $0.04^{*}$ \\
\hline At most $3^{*}$ & 0.42 & 29.80 & 29.80 & $0.05^{*}$ & 18.17 & 21.13 & $0.03^{*}$ \\
\hline At most 4 & 0.21 & 11.63 & 15.50 & 0.18 & 7.86 & 14.26 & $0.03^{*}$ \\
\hline
\end{tabular}

Source: Authors, 2020

Notes: Trace test indicates 4 cointegrating eqn(s) at the $5 \%$ level; Max-eigenvalue test indicates 5 cointegration at the $5 \%$ level; ${ }^{*}$ rejection of the hypothesis at the $5 \%$ level; **MacKinnon-Haug-Michelis (1999) p-values

We confirmed the existence of a long-run relationship since we rejected the null of no cointegration. We proceed to estimate the two-step Engle and Granger estimation procedure.

Table 6 presents the result of the two-step Engle and Granger error correction procedure. The estimated coefficient of the error correction vector was 0.4591 , implying that the error correction term gradually adjusted back to the short-run equilibrating position at the rate of 56.72 per cent. The coefficient of the error correction term was appropriately signed and significant at $1 \%$ level of significance. 
Adekunle, Ogunade, Kalejaiye, \& Balogun

Capital Inflows and Industrial Performance in Nigeria: Including the Excluded

Table 6 Two-Step Engle and Granger Error Correction Result

\begin{tabular}{|c|c|c|c|}
\hline \multicolumn{4}{|l|}{ DEP.VAR: IND OUT } \\
\hline Variable & Coefficient & t-Statistic & Prob. \\
\hline$A$ & 0.1440 & 2.7373 & $0.0001 * *$ \\
\hline$A L_{i t}$ & 0.1193 & 2.6363 & $0.0234^{*}$ \\
\hline$K_{i t}$ & 0.8734 & 2.8562 & $0.0421 *$ \\
\hline FDI & 0.5662 & 3.6372 & $0.0432 *$ \\
\hline REM & 0.1916 & 2.7237 & 0.1255 \\
\hline$O D A$ & -0.4591 & -1.0983 & 0.3014 \\
\hline $\operatorname{PORT}_{I N V}$ & 0.6895 & 2.7281 & $0.0167^{*}$ \\
\hline $\operatorname{ECM}(-1)$ & -0.5672 & -2.9273 & $0.0014^{*}$ \\
\hline R-squared & & 0.7162 & \\
\hline Adjusted $\mathrm{R}^{2}$ & & 0.5129 & \\
\hline F-statistic & & 45.2321 & \\
\hline Prob(F-statistic) & & $0.0000 * *$ & \\
\hline Durbin-Watson stat & & 2.0544 & \\
\hline
\end{tabular}

Source: Authors, 2020

$* *(1 \%) *(5 \%)$ indicates significance levels

The coefficient of error correction implies that about 57\% of the previous year's disequilibrium in the economy's industrial sector was revolved around its short run equilibrating position. Short-run estimates revealed that all the explanatory variables except official development assistance and portfolio investment induced a linear and positive relationship with industrial output growth in Nigeria. Explicitly, a percentage increase in the labour participation rate will result in an 11.93 per cent increase in Industrial Output in Nigeria. Daveri and Tabellini (2000) found similar results for several industrialised economies. Nevertheless, a percentage increase in capital formation will result in an 87.34 per cent increase in Industrial Output in Nigeria. This finding aligns with the work of Oded (2011) and Oketch (2006). Furthermore, a percentage increase in foreign direct investment will result in a $\mathbf{5 6 . 6 2}$ per cent increase in Industrial Output in Nigeria, as also revealed by Onanuga, Odusanaya, and Adekunle (2020). Finally, a percentage increase in portfolio investment will result in a 68.95 per cent increase in Industrial Output in Nigeria, which also corroborating the findings of Onanuga, Odusanaya, and Adekunle (2020). However, remittances and official development assistance were found not to statistically determine industrial output growth in Nigeria at any level of significance. It implies that they did not predict variations in industrial output growth in Nigeria.

The value of the adjusted $R^{2}$ of 0.5129 indicates that explanatory variables of the model explained $51.29 \%$ of variations in industrial output growth in Nigeria, while the remaining $48.71 \%$ were captured outside the model. The Durbin Watson value of 2.0544 implies that the model was free from problems of serial correlation because it fell within the acceptance range of 1.5 to 2.5 . The F-statistics of 45.2321 was statistically significant at the 1 per cent level, indicating that the explanatory variables were jointly significant, suggesting that the model exhibited the desired goodness of fit. 


\section{Granger Causality Test}

In gauging the causation lag order of the capital inflow-industrial output relationship, we regressed the dependent variable " $I N D_{O U T_{t}}$ " on its own one period lag and the oneperiod lag of the regressors. We tested the null hypothesis of joint zero coefficients in the lagged regressors. By inference, failure to reject the null is equivalent to failure to reject the hypothesis that one-period lag of the regressors does not Granger cause industrial output in Nigeria. We expressed the causality model as:

$$
\begin{gathered}
I N D_{O U T_{t}}=\alpha_{o}+\sum_{j=1}^{p_{2}} \beta_{j} A L_{t-j}+\sum_{k=1}^{p_{3}} \beta_{k} \ln K_{t-k}+\sum_{v=1}^{p_{4}} \beta_{l} F D I_{t-v}+ \\
\sum_{m=1}^{p_{5}} \beta_{m} R E M_{t-m}+\sum_{w=1}^{p_{5}} \beta_{w} O D A_{t-w}+\sum_{z=1}^{p_{5}} \beta_{z} P O R T_{I N V}{ }_{t-z}+\mu_{t}
\end{gathered}
$$

To test the non-Granger causality from $A L_{t}, K_{t}, F D I_{t}, R E M_{t}, O D A_{t}$ and $P O R T_{I N V_{t}}$ to $I N D_{\text {OUT }}$, we tested the nullity of all coefficients, $\beta_{j}, \beta_{k}, \beta_{v}, \beta_{m}, \beta_{w}$ and $\beta_{z}$

The pairwise Granger Causality test results are given in Table 7.

\begin{tabular}{|c|c|c|}
\hline Null hypothesis: $X$ does not Granger Cause $Y$ & F-Statistics & Probability \\
\hline$I N D_{\text {oUT }_{t}} \rightarrow A L_{t}$ & 1.6343 & 0.7723 \\
\hline$A L_{t} \rightarrow I N D_{\text {oUT }_{t}}$ & 0.5432 & $0.0043 * *$ \\
\hline$I N D_{\text {oUT }_{t}} \rightarrow K_{t}$ & 2.5362 & 0.4170 \\
\hline$K_{t} \rightarrow I N D_{\text {oUT }_{t}}$ & 0.4378 & $0.0052 * *$ \\
\hline $\mathrm{IND}_{\text {out }_{t}} \rightarrow \mathrm{FDI}_{t}$ & 1.4526 & 0.1238 \\
\hline$F D I_{t} \rightarrow I N D_{o U T_{t}}$ & 4.5623 & $0.0004 * *$ \\
\hline$I N D_{\text {oUT }_{t}} \rightarrow R E M_{t}$ & 0.6272 & 0.6621 \\
\hline$R E M_{t} \rightarrow I N D_{\text {oUT }_{t}}$ & 1.3838 & 0.7372 \\
\hline$I N D_{\text {oUT }_{t}} \rightarrow O D A_{t}$ & 2.9213 & 0.5366 \\
\hline$O D A_{t} \rightarrow I N D_{\text {oUT }_{t}}$ & 2.6782 & 0.3521 \\
\hline IND $_{\text {oUT }_{t}} \rightarrow \mathrm{PORT}_{\text {INV }_{t}}$ & 0.6342 & 0.9882 \\
\hline $\mathrm{PORT}_{I N V_{t}} \rightarrow \mathrm{IND}_{\text {OUT }_{t}}$ & 2.8821 & $0.0234 *$ \\
\hline
\end{tabular}

Table 7 Granger Causality Result

Source: Authors, 2020

$* *(1 \%) *(5 \%)$ indicates significance levels

The result in Table 7 indicates that there is unidirectional causality from labour participation, gross fixed capital formation (a measure of capital), FDI, and portfolio investment to industrial output growth in Nigeria. Hence, labour participation, gross fixed capital formation, $\mathrm{FDI}$, and portfolio investment granger caused industrial output growth in Nigeria. The findings of this study agree with the findings of Singh (2012).

Table 8 Serial Correlation Test

\begin{tabular}{llll}
\hline \multicolumn{3}{l}{ Breusch-Godfrey Serial Correlation LM Test: } & \\
\hline F-statistic & 0.5262 & Prob. F $(7,24)$ & 0.2312 \\
Obs*R-squared & 2.6263 & Prob. Chi-Square (7) & 0.4552 \\
\hline
\end{tabular}

Source: Authors, 2020 
Given the probability value of 45.52 per cent, we failed to reject the null hypothesis and concluded that our short-run model was free from problems of serial correlation.

Table 9 Heteroscedasticity Test Result

\begin{tabular}{llll}
\hline \multicolumn{4}{l}{ Breusch-Pagan-Godfrey Heteroscedasticity Test: } \\
\hline F-statistic & 0.565126 & Prob. F (7,24) & 0.5357 \\
Obs*R-squared & 10.75370 & Prob. Chi-Square (7) & 0.9273 \\
\hline
\end{tabular}

Source: Authors, 2020

Given the probability value of 92.73 per cent, we failed to reject the null hypothesis and concluded that our short-run model was free from problems of heteroskedasticity.

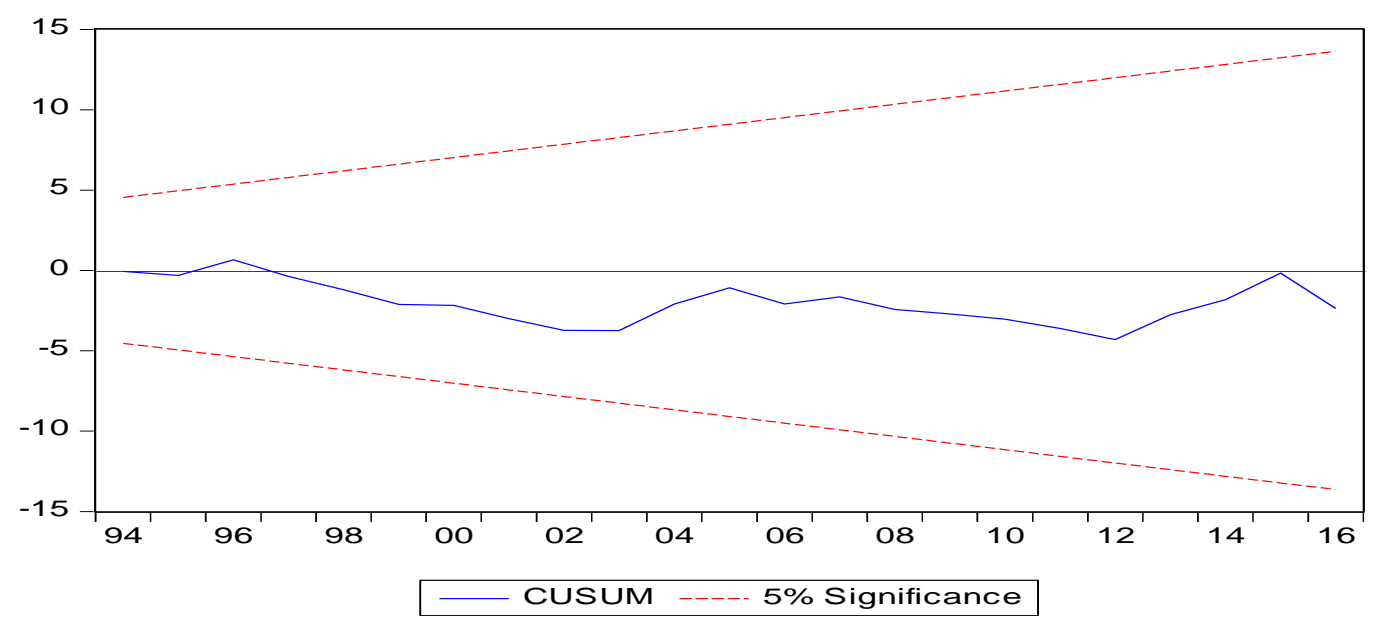

Figure 1 CUSUM Stability Test

Source: Authors, 2020

The above figure shows that the CUSUM line is within the critical bounds of 5 per cent level of significance, which indicates that the model had structural stability.

\section{Conclusion}

Despite the significance of capital outsourcing as an alternative source of investment financing, the empirical connections between capital inflows and industrial output growth in Nigeria remain grossly understudied. Previous studies on the industrial development discourse in Nigeria have focused on the influence of exchange rate volatility or fluctuations in the industrial sector development literature in Nigeria. Little was done to establish the contemporaneous influence of the various source of capital inflow on industrial sector growth. Which of these channels of capital inflows is more pervasive and efficient? It is an important research question for policy information research redefinition in Nigeria. This study relied on aggregate indices of capital inflows (remittances inflows, official development assistance (ODA), FDI inflows, and portfolio investment) and industrial sector development from 1987 through 2017 to lean empirical credence to the 
relationship. We found that an increased labour participation rate was essential for the increase in industrial output in Nigeria, just as Daveri and Tabellini (2000) have stressed in their findings. Domestic and international capital inflow jointly aided narrowing a wide investment gap in Nigeria, which is in consonance with Oded (2011); Oketch (2006) and Onanuga, Odusanaya, and Adekunle (2020). However, remittances and official development were anathemas to industrial output growth in Nigeria, mainly owing to the unproductive role remittances play in the African space. Remittances are mainly used for consumption, which in pure form does not generate a return in itself. Development assistance is usually mismanaged owing mainly to the political motives that are associated. Labour participation, gross fixed capital formation, FDI, and portfolio investment granger caused industrial output growth in Nigeria, thus, corroborating the findings of Singh (2012). This study's novelty is two-fold. Firstly, it leads to the debate on capital inflows and industrial sector development in Nigeria. Secondly, this study relied on the two-step Engle and Granger estimation procedure to establish a baseline asymptotic relationship between capital inflow and industrial sector performance in Nigeria.

Based on the findings, this paper recommends that Nigerian government should see inflows of foreign capital as a viable catalyst that can propel the expansion of the country's industrial sector, and the policymakers in the economy should embark on policy measures that will ensure the sustainability of foreign direct investment inflows and external debt towards the direction of industrial sectors in Nigeria. In the same vein, a more significant percentage of remittances should be tailored towards the industrial sector in the country. If their foreign capital flows are sustained, there will be an industrial revolution in the economy in the nearest future.

This study is limited to the facts obtained from the interactions of aggregates data on capital inflow and industrial output growth in Nigeria between 1987 through 2018.

\section{References}

Aizenman, J., Pinto, B., \& Radziwill, A. (2007). Sources for financing domestic capital - Is foreign saving a viable option for developing countries? Journal of International Money and Finance. 26(5), 682-702. https://doi.org/10.1016/j.jimonfin.2007.04.009

Akinlo, A. E. (2004). Foreign direct investment and growth in Nigeria. Journal of Policy Modeling, 26(5), 627-639. https://doi.org/10.1016/j.jpolmod.2004.04.011

Aryeetey, E., \& Moyo, N. (2012). Industrialisation for structural transformation in Africa: Appropriate roles for the state. Journal of African Economies, 21(2), 55-85. https://doi.org/10.1093/jae/ jir043

Bandyopadhyay, S., Sandler, T., \& Younas, J. (2014). Foreign direct investment, aid, and terrorism. Oxford Economic Papers, 66(1), 25-50. https://doi.org/10.1093/oep/gpt026

Bezić, H., Galović, T., \& Mišević, P. (2016). Utjecaj terorizma na izravna strana ulaganja (FDI) zemalja EU i EEA. Zbornik Radova Ekonomskog Fakultet Au Rijeci, 34(2), 333 362. https://doi.org/10.18045/zbefri.2016.2.333

Brandl, B., \& Traxler, F. (2010). Labour conflicts: A cross-national analysis of economic and institutional determinants. European Sociological Review, 26(5), 519-540 https://doi.org/10.1093/esr/jcp036 


\section{Adekunle, Ogunade, Kalejaiye, \& Balogun \\ Capital Inflows and Industrial Performance in Nigeria: Including the Excluded}

Bräutigam, D., \& Xiaoyang, T. (2011). African Shenzhen: China's special economic zones in Africa. Journal of Modern African Studies, 49(1), 27-54. https://doi.org/10.1017/S0022278X10000649

Buera, F. J., \& Shin, Y. (2017). Productivity growth and capital flows: The dynamics of reforms. American Economic Journal: Macroeconomics, 9(3), 147-185.

https://doi.org/10.1257/mac.20160307

Calvo, G. A. (1998). Capital Flows and Capital-Market Crises: The Simple Economics of Sudden Stops. Journal of Applied Economics, 1(1), 35-54. https://doi.org/10.1080/15140326.1998.12040516

Carter, M. R., \& May, J. (1999). Poverty, livelihood and class in rural South Africa. World Development, 27(1), 1-20. https://doi.org/10.1016/S0305-750X(98)00129-6

Daveri, F., \& Tabellini, G. (2000). Unemployment, growth and taxation in industrial countries. Economic Policy, 15(30), 48-104. https://doi.org/10.1111/1468-0327.00057

De Gregorio, J., \& Guidotti, P. E. (1995). Financial development and economic growth. World Development, 23(3), 433-448. https://doi.org/10.1016/0305-750X(94)00132-I

De Vita, G., \& Kyaw, K. S. (2008). Determinants of capital flows to developing countries: A structural VAR analysis. Joumal of Economic Studies, 35(4), 304-322. https://doi.org/10.1108/01443580810895608

Edwards, S. (1990). Capital Flows, Foreign Direct Investment, and Debt-Equity Swaps in Developing Countries. NBER Workng Paper, (3497), 1-44. https://doi.org/10.3386/w3497

Efobi, U., \& Asongu, S. (2016). Terrorism and capital flight from Africa. International Economics, 148, 81-94. https://doi.org/10.1016/j.inteco.2016.06.004

Eichler, M. (2007). Granger causality and path diagrams for multivariate time series. Journal of Econometrics, 137(2), 334-353. https://doi.org/10.1016/i.jeconom.2005.06.032

Engle, R. F., \& Granger, C. W. J. (2015). Co-integration and error correction: Representation, estimation, and testing. Applied Econometrics, 39(3), 107-135. https://doi.org/10.2307/1913236

Filer, R. K., \& Stanišić, D. (2016). The Effect of Terrorist Incidents on Capital Flows. Review of Development Economics, 20(2), 502-513. https://doi.org/10.1111/rode.12246

Galović, T., Bezić, H., \& Mišević, P. (2018). Terrorist activities and capital flows of developed countries. Acta Oeconomica, 68(3), 337-352. https://doi.org/10.1556/032.2018.68.3.2

Gourinchas, P. O., \& Jeanne, O. (2006). The elusive gains from international financial integration. Review of Economic Studies, 73(3), 715-741. https://doi.org/10.1111/j.1467937X.2006.00393.x

Herzer D., Klasen .S., \& Nowak-Lehmann, D. F. (2006). In Search of FDI-Led Growth in Developing Countries: The way Forward. Ibero American Institute for Economic Research. Retrieved from https://www.econstor.eu/bitstream/10419/27440/1/517167328.PDF

Levine, R. (1997). Financial Development and Economic Growth: Views and Agenda. Journal of Economic Literature, 35(2), 688-726. https://doi.org/10.1596/1813-9450-1678

Mahipal \& Prasad, B. (2004). Noise pollution and control. In Environmental Pollution and Control (4th Ed). Butterworth-Heinemann: Elsevier Inc. https://doi.org/10.1016/b978-075069899-3/50024-9

Markusen, A. (1996). Sticky places in slippery space: A typology of industrial districts. Economic Geography, 72(3), 293-313. https://doi.org/10.2307/144402

Morris, M., \& Fessehaie, J. (2014). The industrialisation challenge for Africa: Towards a commodities based industrialisation path. Journal of African Trade, 1(1), 25-36. https://doi.org/10.1016/i.joat.2014.10.001 


\section{Adekunle, Ogunade, Kalejaiye, \& Balogun \\ Capital Inflows and Industrial Performance in Nigeria: Including the Excluded}

Oded, G. (2011). Inequality, Human Capital Formation, and the Process of Development. In Handbook of the Economics of Education, 4, 441-493. https://doi.org/10.1016/B978-0444-53444-6.00005-5

Ogun, O., Egwaikhide, F.O. and Ogunleye, E.K. (2012). Real Exchange Rate and Foreign Direct Investment in Sub-Saharan Africa. Economia Mexicana, 21 (1), 172-202. Retrieved from

https://scholar.google.com/scholar?oi=bibs\&cluster=4441786639830814984\&btnI= $\underline{1 \& h l=e n}$

Ojo, J.A.T. \& Alege, P.O. (2010). Global Financial and Macroeconomic FluctuationImplication for African Economic Development. African Economic and Business Review, 8(2), 48-82.

Okereke, C., Coke, A., Geebreyesus, M., Ginbo, T., Wakeford, J. J., \& Mulugetta, Y. (2019). Governing green industrialisation in Africa: Assessing key parameters for a sustainable socio-technical transition in the context of Ethiopia. World Development, 115, 279-290. https://doi.org/10.1016/j.worlddev.2018.11.019

Oketch, M. O. (2006). Determinants of human capital formation and economic growth of African countries. Economics of Education Review, 25(5), 554-564. https://doi.org/10.1016/i.econedurev.2005.07.003

Onanuga, A. T., Odusanya I.A. \& Adekunle I. A. (2020). Terrorism and Financial Flows in Africa. Journal Behavioral Sciences of Terrorism and Political Aggression, 1-18. https://doi.org/10.1080/19434472.2020.1736128

Opperman, P., \& Adjasi, C. K. D. (2017). The determinants of private capital flow volatility in Sub-Saharan African countries. Research in International Business and Finance, 42, 312 320. https://doi.org/10.1016/j.ribaf.2017.07.146

Oseni, I. O., Adekunle, I. A., \& Alabi, M. O. (2019). Exchange rate volatility and industrial output growth in Nigeria. Journal of Economics and Management, 38(4), 129-156. https://doi.org/10.22367/jem.2019.38.07

Osinubi, T. S., \& Amaghionyeodiwe, L. A. (2010). Foreign private investment and economic growth in Nigeria. Applied Econometrics and International Development, 10(2), 189-204. Retrieved from http://www.usc.es/economet/reviews/aeid10215.pdf

Oyelaran-Oyeyinka, B. (2014). The state and innovation policy in Africa. African Journal of Science, Technology, Innovation and Development, 6(5), 481-496. https://doi.org/10.1080/20421338.2014.983731

Pesaran, M. H., \& Shin, Y. (2012). An Autoregressive Distributed-Lag Modelling Approach to Cointegration Analysis. In Econometrics and Economic Theory in the 20th Century, 371413, Cambridge: Cambridge University Press. https://doi.org/10.1017/cbo9781139052221.011

Prasad, E. S., Rajan, R. G., \& Subramanian, A. (2007). Foreign capital and economic growth. In Brookings Papers on Economic Activity. https://doi.org/10.1353/eca.2007.0016

Rajan, R. G., \& Zingales, L. (1998). Financial Dependence and Growth. American Economic Review, 88(3), 559-586. https://doi.org/10.2307/116849

Reisen, H., \& Soto, M. (2001). Which types of capital inflows foster developing-country growth? International Finance, 4(1), 1-14. https: / doi.org/10.1111/1468-2362.00063

Schneider, B. (2003). Measuring capital flight: estimates and interpretations. Working Paper 194 of the Overseas Development Insitute. Retrieved from https://www.files.ethz.ch/isn/100552/wp194.pdf

Singh, T. (2012). Does public capital crowd-out or crowd-in private capital in India? Journal of Economic Policy Reform, 15(2), 109-133. https://doi.org/10.1080/17487870.2012.668767 
Taylor, I. (2016). Dependency redux: why Africa is not rising. Review of African Political Economy, 43(147), 8-25. https://doi.org/10.1080/03056244.2015.1084911

Ugwu, J. O., Asogwa, F. O., \& Ugwuanyi, R. O. (2017). The Relative Impact of External Capital on Manufacturing Output in Nigeria. Journal of Economics and Sustainable Development. 8(8),158-167. https:// doi.org/10.7176/jesd/10-3-02

Wang, Q., \& Wu, N. (2012). Long-run covariance and its applications in cointegration regression. Stata Journal, 12(3), 515-542. https://doi.org/10.1177/1536867x1201200312

World Bank. (2013). Africa Development Indicators 2012/2013. Retrieved from https:// doi.org/10.1596/978-0-8213-9616-2

World Bank. (2014). Nigeria Economic report. World Bank. Retrieved from https://doi.org/10.1007/BF02315996

World Development Indicators (2010). Retrieved from https://doi.org/10.1596/978-0$\underline{8213-8232-5}$ 